\title{
The Influence of Social Support on the Academic Performance/Self- Efficacy of Students in Methodist University College Students, Ghana
}

\author{
Peter Worlanyo Abomah \\ Methodist University College Ghana, Department of Social Sciences, Dansoman Accra \\ Ghana
}

\begin{abstract}
The study examined the influence of social support on the academic performance/self-efficacy of students at Methodist University College, Ghana. The purpose is to examine whether social support influence academic performance, examine whether gender differences exist in social support students receives and their academic performance, explore how high resilience self-will predict academic performance. The research design employed was a survey. One hundred and twenty students were selected for the study from four faculties of the University using stratified proportional and simple random sampling methods. The standardized instrument of medical outcome social support survey scale, the academic self-efficacy scale, and the resilience scale were used. Four hypotheses were analyzed. The results indicate that a positive relationship between social support leads to good academic performance. There was no difference in terms of social support and academic performance by female and male students. Students with high resilience had high academic attainments. Social assistance does not influence the academic self-efficacy of students. It is recommended that Universities and higher institutions of learning should have well-functioning counselling centres.
\end{abstract}

Keywords: Academic self-efficacy, Depression, Emotional Support, Psychological distress, Stress, Social Support.

\section{Introduction}

According to [1], going through university education is stressful. There realization that this stressful nature of the university education may take a toll on the mental health of the students, which may have an effect on their academic performance/self-efficacy. Social support serves as an important role when it comes to academic performance. It is very important to review the role of social support serves as a cushion against the stresses of life, which in the long run serves to promote good mental health [2].

The transition to university education and environment could result in all forms of stress and shock to students due to the difference in secondary education and university education [3]. It is not clear whether most students in tertiary institutions who experience stress and minor psychological distresses have access to or take advantage of the right type of social support as well as help-seeking environments such as the counseling centers in their various institutions or from their peers and family. As such, this study also aims at finding out whether the students take advantage of the social support from the counseling centers in their various institutions or from their peers and family when they experience minor psychological distress.

The study aims to examine the influence of this social support, psychological distress, on academic performance. It is assumed that the constant struggle by some students to excel academically may be due to lower social encouragement from family and friends and psychological distress. Recognized 
internationally as an important public health issue is the mental health of university students. It was found that psychological distress was linked to mental disability and lower academic achievement [4], [1]. There is a special pattern of distress that adolescents experience [5]. It may also go unnoticed if the lack of social encouragement from family relations, friends, and psychological distress is a contributing factor to low academic performance. According to [6], parental support has a positive influence on the academic performance and self consept of students. According to [7], Low self-esteem is a behavioural disorder which tends to effect the learning and performance of children in schools. There is a need to conduct studies to understand the burden of mental health issues among university students in this part of our world. This will guide interventions that decrease the risk and improve psychological well-being and promote the desire for adequate social encouragement from family and friends. This may result in improved academic performance. According to [8] academic anxiety correlates with academic performance. The study supports the finding of Abomah [9] academic anxiety leads to examination malpractices.

The results of [10] states that university engagement measures were positively related to students' learning achievement indicators The results of [11] indicates that depressive symptom increases the risk for academic problems It also support the findings of [12] that economic effects, and the effects on daily life, as well as delays in academic activities, were positively associated with anxiety symptoms

This happens if the basic gaols of humans as outlined by [13] are not met. The findings of [14] indicates that encouragement to achieve, the provision of care and support to deal with problems in a proactive manner and enabling relationship with significant others facilitated academic achievement dispute exposure to violence.
Even though some literature exists on the intervening variables between informal social support, psychological well-being, and academic performance, more extensive research should be conducted to get a broader idea of the ways in which social support from informal social networking between family and friends and how psychological distress relates to academic performance among university students. Therefore, the purpose of this study is to find out the kind of effect that social support from family and friends and psychological distress/resilience has on university students' academic performance. The objectives include to explore whether university students experience psychological distress, to examine gender differences that exist in the social encouragement students receive, to examine differences that exist in psychological distress There should be continuous research to improve tertiary education for knowledge society [15]. Hence the study indicates that students face, and to explore how psychological distress and social support influence academic performance/self-efficacy of students. The following hypotheses were tested. A significant correlation exists between social encouragement and academic self-efficacy. Females will report higher levels of social encouragement than their male counterparts. There will be a significant influence of social assistance and psychological distress on academic performance.

\section{Methods}

The survey was the research design used because the research provided information about the distribution of a wide range of the characteristics that are being looked for in this study. The population of interest for the study was the undergraduate students from all the faculties at Methodist University College. These were students pursuing degree courses from level 200 to level 300 of the University. The sample frame involves the level 200 and 300 students because they were the stable 
groups whilst the level 100 students were settling into the school, and the level 400 students were preparing to leave.

The sampling technique employed was simple random and stratified proportional method. Using the sampling technique, 120 undergraduate students were sampled for the study. There were four faculties at MUCG, which were the Business Administration faculty, the Informatics and Mathematical Sciences faculty, the Social Studies faculty, and the Arts and General Study's faculty. Thirty (30) students were selected from each faculty to reflect the numerical composition of four faculties within MUCG. This gave a total sample of one hundred and twenty (120) students.

The instrument was developed by [16]. A self-report tool made up of 19 items on a fivepoint Likert scale, thus how frequently they rely on others for support in various circumstances, was used. This survey used four distinct subscales of social assistance and a general functional social support index. The survey has Cronbach alphas greater than .91 for all factors and is fairly stable over time. An individual scale with the highest score or the overall support index indicates more social support. The academic self-efficacy scale was developed by [17] for measuring academic self-efficacy. This instrument is made up of 8 items on a 7point Likert scale that ranged. The scale has a Cronbach alpha reliability coefficient of 0.81 used for undergraduates. It also has high reliability. The item includes scores on the academic self-efficacy scale range from seven (7) to forty-nine. The RS measured psychological resilience and was created by
[18]. It consists of 25-items. This scale also comes in a short form which is termed (RS-14). Both the RS and RS-14 have Cronbach's $\alpha$ range of 0.72-0.94. The instruments (RS and RS-14) have their scoring done on a Likert scale of 1-7.

The scores group the partakers into low, moderate, and high resilience scores. Scoring for Medical Outcomes Study Social Support Survey (MOS-SSS) was used. Scoring for each scale was done by finding the average of the scores for each and every item on that subscale. For the overall support index, one has to calculate the average of first the scores of 18 items in the four subscales and the score for the extra additional item. In scoring for the Academic Self-Efficacy, the higher the score is indicative of a higher level of academic selfefficacy, the lower the scores respectively. There was scoring for the Resilience Scale (RS).

The total score ranges between 25 and 175 points. Scores exceeding 161 indicate a very high degree of resilience, among 146-160 a high, 131-145 a moderate, 116-130 low, and scores below 100 indicate a very low degree of resilience capacity [19]. Students' data such as age, religion, gender, marital status, level of study, and live on campus or not were collected. In demographics data, the students were asked to state their CGPA (which was their Cumulative Grade Point Average at the time of collecting data).

\section{Result}

Four hypotheses were analyzed, each with their appropriate statistical test.

Table 1. Representation of Respondents Gender, Age, Religion, Marital Status, Year/Level, Residential Status, and CGPA

\begin{tabular}{|l|l|l|l|l|}
\hline Groups & Frequency & Percent & Mean & Std. Deviation \\
\hline Gender & 3 & 2.5 & & \\
\hline Missing Data & 50 & 41.7 & & \\
\hline Male & 67 & 55.8 & & \\
\hline Female & \multicolumn{5}{|l}{} & & \\
\hline
\end{tabular}




\begin{tabular}{|l|l|l|l|l|}
\hline Total & 120 & 100 & & \\
\hline Age (Mean, SD) & 24.63 & 7.08 & & \\
\hline Religion & 2 & 1.7 & & \\
\hline Missing Data & 115 & 95.8 & & \\
\hline Christianity & 2 & 1.7 & & \\
\hline Islam & 1 & 0.8 & & \\
\hline Other & 120 & 100 & & \\
\hline Total & 1 & 0.8 & & \\
\hline Marital Status & 105 & 87.5 & & \\
\hline Missing Data & 13 & 10.8 & & \\
\hline Single & 1 & 0.8 & & \\
\hline Married & 120 & 100 & & \\
\hline Separated & \multicolumn{1}{|l|}{} & & \\
\hline Total & 68 & 56.7 & & \\
\hline Year/Level & 52 & 43.3 & & \\
\hline 200 & 120 & 100 & & \\
\hline 300 & 3 & 2.5 & & \\
\hline Total & 23 & 19.2 & & \\
\hline Residential Status & 94 & 78.3 & & \\
\hline Missing Data & 120 & 100 & & \\
\hline On Campus & & & 1.69 & 1.54 \\
\hline Off Campus & & & \\
\hline Total & & & \\
\hline Cumulative GPA & & & \\
\hline
\end{tabular}

Table 1 indicates that $47 \%$ of respondents were males, while $53 \%$ were females. The mean age was 24.63 years, while the standard deviation was 7.08 years. $95.8 \%$ were Christians, $1.7 \%$ belonged to the Islamic religion, and $0.8 \%$ belonged to other religions. Again $87.5 \%$ were single, while $10.8 \%$ were married, and $0.8 \%$ were separated. Also, $56.7 \%$ were in level 200, whiles $43.3 \%$ were in level 300. Under residential status, $19.2 \%$ lived on campus, while $78.3 \%$ lived off-campus. The mean for the cumulative grade point average was 1.69 , and the standard deviation was 1.54.

Table 2. Mean and Standard Deviation for Social Support, Academic Self-efficacy, and Resilience

\begin{tabular}{|l|l|l|}
\hline Variables & M & SD \\
\hline Social Support & 65.64 & 15.81 \\
\hline Academic Self-Efficacy & 43.01 & 11.37 \\
\hline Resilience & 137.73 & 23.45 \\
\hline
\end{tabular}

Table 2 indicates the mean and standard deviations of social support (Mean=65.64, $\mathrm{SD}=15.81), \quad$ academic self-efficacy (Mean=43.01, $\mathrm{SD}=11.37$ ), and resilience (Mean=137.73, $\mathrm{SD}=23.45)$
Testing of Hypotheses: Hypothesis One; A significant positive correlation exists between social assistance and academic self-efficacy. 
Table 3. Pearson Product Moment Correlation Coefficient Test Results on the Relationship between Social Support and Academic Self-Efficacy

\begin{tabular}{|l|l|l|l|l|}
\hline Variables & M & SD df & r & P \\
\hline Social Support & 65.64 & 15.81 & & \\
\hline Academic Self -Efficacy & 43.01 & 11.37 & & \\
\hline & & & .184 & .022 \\
\hline
\end{tabular}

Table 3 indicates that the mean for social assistance $(M=65.64, S D=15.81)$ and academic self-efficacy/performance

$(\mathrm{M}=43.01$, $\mathrm{SD}=11.37$ ) were administered to the Pearson Product Moment Correlation Coefficient test to determine whether a significant positive relationship exists between social support and academic self-efficacy. Results ( $\mathrm{r}-.184, \mathrm{p}=.022)$ indicated that the correlation between social support and academic self-efficacy/performance is significantly positive. This implies that social support predicts academic self-efficacy. Hypothesis one is supported. Hypothesis Two: Females will report higher levels of social assistance compared to their male counterparts. The results are presented in Table 4.

Table 4. Independent T-Test Result between Females Social Assistance and Males Social Support

\begin{tabular}{|l|l|l|l|l|l|l|}
\hline Group & N & M & SD & df & t & P \\
\hline Females Social Assistance Scores & 67 & 65.96 & 17.00 & 115 & -17 & .86 \\
\hline Males Social- Assistance Scores & 50 & 65.44 & 14.50 & & & \\
\hline$* p<0.05$ &
\end{tabular}

Results indicate no significant difference in the amount of social assistance received by females $(\mathrm{M}=65.96, \quad \mathrm{SD}=17.00)$ and males $(\mathrm{M}=65.44, \quad \mathrm{SD}=14.50) ; \quad(115)=-.17, \mathrm{p}=.86$. Therefore, the hypothesis that females will report higher levels of social assistance compared to male counterparts was not supported. Hypothesis three: There will be a significant influence of social assistance and psychological distress on academic selfefficacy. The results are presented in Table 5.

Table 5. Linear Regression on how Social Assistance and Psychological Distress (Resilience) can Predict Academic Self-efficacy

\begin{tabular}{|l|l|l|l|l|}
\hline Variables & B & SE & $\boldsymbol{\beta}$ & $\boldsymbol{P}$ \\
\hline (Constant) & 19.07 & 6.60 & - & .005 \\
\hline Social Assistance & .090 & .065 & .12 & .170 \\
\hline Resilience & .131 & .044 & .271 & .003 \\
\hline $\mathrm{R}^{2}=.104$ & \multicolumn{4}{|l}{} \\
\hline
\end{tabular}

The analysis in Table 5 shows that social assistance does not influence academic selfefficacy but resilience (psychological distress) does influence academic performance/selfefficacy; social assistance $(\mathrm{t}=1.381, \mathrm{p}=.170)$, and resilience $(\mathrm{t}=3.016, \mathrm{p}=.003)$.

\section{Conclusion}

It was found that high social assistance predicted high academic performance. No significant difference in the amount of social assistance and academic performance of female and male's students. It was also found that high resilience (low level of psychological distress) predicted high academic self-efficacy.

\section{Discussion}

The results from the data analysis revealed that there is no difference in the level of social support and academic performance by both men and women. A study conducted by [7] compared the academic performance of primary school children with behavioral disorders. More males than females had behavioral disorders in 
this study. The result indicated that the relationship between social assistance and psychological problems was a negative one. This confirms the findings of [19-21] that parental school involvement improves the academic performance of children. The findings of this study indicated that social assistance was positively correlated to academic self-efficacy or performance. As such, the more social support students receive, the more their academic self-efficacy/performance increases. There is no significant difference in the amount of social assistance received by males and females. The study indicates that social support does not influence academic self-efficacy, but resilience (psychological distress) does influence academic performance. The study reveals that there might be more issues surrounding students' poor academic selfefficacy/performance. Therefore, different variables could be examined to ascertain their influence on the academic selfefficacy/performance on students. The study revealed that social assistance and resilience predict the academic performance of students. Good social assistance predicts good academic performance.

\section{References}

[1] Pidgeon, A., Rowe, N. F., Stapleton, P., Magyar, H. B. \& Lo, B. C. Y. (2014). Examining Characteristics of Resilience among University Students: An International Study.Open Journal of Social Sciences, 2 (11), 14-22. Retrieved from https://epublications.bond.edu.au/fsd_papers/176/.

[2] Dollete, M., Steese, S., Phillips, W., Taormina, G., \& Matthews, G. (2004). Understanding girls' circle as an intervention on perceived social support, body image, self-efficacy, locus of control and selfesteem. The Journal of Psychology,90 (2), 204 -215. [3] Thawabieh, A.M., \& Qaisy, L.M. (2012). Assessing Stress among University Students. American International Journal of Contemporary Research, $2 . \quad$ Retrieved from https://www.aijcrnet.com/journals/Vol_2_No_2_Feb ruary_2012/13.pdf.

\section{Conflict of Interest}

Author declares that there is no conflict of interest.

\section{Implications and Recommendations}

The existence of the counseling centers on university campuses and their benefits to the students should be explained to students during orientation programmes. Mental health professionals should place emphasis on being more empathetic in their practice to boost the social assistance they give to their clients. Also, the mental health professionals should also identify clients who have adequate psychological resilience and guide them in coping skills they could use.

\section{Acknowledgement}

The study was conducted in the academic institution that the researcher works, but all ethical standards were followed. There were some missing data when cumulative grade point was being collated to serve as confirmation of academic self-efficacy. Acknowledgement to all sources cited in this work and respondents consulted.

[4] Stallman. (2010). Psychological distress in university students: A comparison with general population data. Australian Psychologist, 45(4).

[5] Mirowsky, J. Ross, C. E.1996. Social patterns of distress. Annual Review of Socialogy, 12, 23-45.

[6] Chohan, B.I., \& Khan R.M. (2010). Impact of Parental Support on the Academic Performance and Self-Concept of the Student. Journal of Research and Reflections in Education, 4. 14-26. Retrieved from

https://www.researchgate.net/publication/216035869 _Impact_of_Parental_Support_on_the_Academic_P erformance_and_Self_Concept_of_the_Student.

[7] Akpan, M.U., Ojinnaka, N.C., \& Ekanem, E.E. (2010). Academic performance of school children with behaviour disorders in Uyo, Nigeria. African Health Sciences, 10 (2), 154-158. 
[8] Shakir, M. [2014]. Academic Anxiety as a correkate of Academic Achievement. Journal of Education and Practice5, Retrieved from http://citeseerx.ist.psu.edu/viewdov/download?doi10 .1.1.840.7365\&rep=rep1\&type-pdf.

[9] Abomah, P. W. (2013). Student's attitudes towards examination malpractices: A case study of Methodist University College Ghana. International Journal of Research in Education. (10) 1.

[10] Yu, L. Shek, D. T. L. Zhu, X. [2018]. The influence of personal well-being on learning achievement in university students over time: Mediating or moderating effects of internal and external University engagement. Frontiers of $\begin{array}{lllll}\text { Psychology } 9 & 9287 & \text { Retrieved from }\end{array}$ https://www.nebi.Nih.gov/pulmed/2937521.

[11] Tuner, D. P. Thompson, M. E. Huber, L. R. B. \& Arif A. A. \{2012\} Depressive Symptoms and Academic Performance of North Carolina College Students. North Carolina Medical Journal, 73 \{3\} 169-175.

[12]Cao, W. Fang, Z. Hou, G. Han, M. Xu, X. Dong, J. et al [2020]. The psychological impact of the COVID-19 epidemic on college students in China. Psychiatry Research 2020:112934. Doi:10. 1016/j. psycgres.2020.112934.

[13] Maslow, A. H. $\{1943\}$. The theory of human motivation Psychological Review 50, 370-396.

[14] Judel, L. \{2014\}. Perception regarding the role of social support in the Academic Achievement of Adolescents Exposed to Violence. North West University. Potchefstroom Campus.

[15]OECD. $\{2008\}$ Tertiary Education for the Knowledge Society. OECD Thematic Review of Education: Synthesis Report. April 2008.
[16] Chemers M, Martin \& Hu, Li-tze \&Garcia F, B. (2001). Academic self-efficacy and first-year college student performance and adjustment. Journal of Educational Psychology. 93. 55-64. 10.1037/00220663.93.1.55. Retrieved from https://www.researchgate.net/publication/232450523 _Academic_self-efficacy_and_firstyear_college_student_performance_and_adjustment. [17] Wagnild, G.M., \& Young, H, M. (1987) How Resilient Are You? Retrieved from http://www.resiliencescale.com/en/rstest/rstest_25_e n.html.

[18] Wagnild, G.M., \& Young, H, M. (2009). Resilience Scale - A Reliable and Valid tool to Measure Resilience. Retrieved from http://www.resiliencescale.com.

[19]Duncan-Williams, B. (2015). Academic stress, academic performance and the psychological wellbeing of senior high school remedial students in the Greater-Accra region of Ghana. (Unpublished master's thesis). University of Ghana Legon.

[20]Nyarko, K. $\{2011\}$ Parental School Involvement: The case of Ghana. Journal of Emergency Trendsin Educational Research and Policy Studies. 2\{5\},378-381.

[21] Ye, Y, Huang, X. \& Liu, Y. [2021] Social support and academic burnout among university students: A mediation model. Journal of Psychology Research and Behaviour Management. [14] 335344. 